AGROLAND: The Agricultural Sciences Journal

Vol. 8, No. 1 June (2021), 21 - 30

P-ISSN : 2407- 7585 \& E-ISSN : 2407- 7593, Published by Tadulako University

\title{
THE DIFFERENCE OF BEHAVIOR AND MANGO FARMERS' INCOME IN IMPLEMENTING OFF SEASON AND ON SEASON FARMING
}

\author{
Esa Noerbayinda $^{1) *}$, Eliana Wulandari ${ }^{1)}$ \\ ${ }^{1)}$ Agribusiness Study Program, Faculty of Agriculture, Universitas Padjadjaran Correspondence \\ author's: Esa Noerbayinda \\ Email : esanoerby01@gmail.com
}

Submit: 20 Januari 2021, Revised: 30 Januari 2021, Accepted: June 2021

https://doi.org/10.22487/agroland.v0i0.691

\begin{abstract}
The production of gedong gincu mango tends to be abundant lead to the selling price could decrease. Mango farmers in Jatibarang Sub-district had implemented off season farming as a solution to maintain the availability of mango production throughout the year which would have implications on the rising selling price. The behavior of farmers in on and off season could be different that may affect the cost, sale price and income of farmers. This study aims to analyze the differences behavior gedong gincu mango farmers in on and off season as well as its effect on their income. This research was conducted using survey method. The data analysis used a descriptive statistic, Mann Whitney tests and income analysis. The results showed no difference in farmers' behavior in terms of fertilization and pruning frequency. Farmers in Jatibarang Sub-district as a whole have implemented off season farming so that there are differences in behavior in terms of the spraying frequency and applying paclobutrazol. Off season farming was more profitable than on season farming, with the average selling price reached IDR 25,200 per $\mathrm{kg}$ and average income of IDR $52,680,594$. Therefore, off season farming could be an option to increase farmers' income.
\end{abstract}

Keyword: Behavior, Income, Mango, On season, Off season.

\section{INTRODUCTION}

The development of horticultural commodities as an alternative source of community economy in the agricultural sector continues to have attention from various parties to be commercialized. According to Bakhsh et al. (2006), mango farming is an activity that provides benefits for farmers. Mango is one of the commercial commodities of horticulture that has potential to be developed, as its increasing of the production every year. According to annual Vegetable and Fruit Statistics data for 2018, annual fruit production increased compared to 2017 and the largest increase occurred in mango production by 420,998 tons or 19.1 percent.

One of the centers of mango production in Indonesia is West Java Province. The area of West Java which is the center of mangoes include Indramayu, Majalengka, Sumedang, and Cirebon 
Districts. This can be seen in Table 1 which is mango production data according to the Central Bureau of Statistics of West Java in 2018.

Table 1 shows the Indramayu District is the district with the highest mango production from 2014-2018 in West Java Province. There are four main types of mango cultivated in Indramayu District, namely sweet harum manis mango, gedong gincu, cengkir, and golek. According to Dittmar and Drury (2000) packaging of mangoes will not affect the consumers' preference to consume mangoes, so mangoes still have competitive value even if not packaged. The type of mango that has the mo-st competitive value is gedong gincu mango because it has uniqueness in terms of taste, shape, and aroma so that it becomes the type of mango with the highest selling price. According to Rizkia (2012) the selling price of gedong gincu mango can reach more than IDR 20,000 per $\mathrm{kg}$. Although the selling price is high, gedong gincu mango tends to be preferred by consumers (Hadayanti et al. 2016).

Table 1. Mango Production by District (Ton)

\begin{tabular}{llccccc}
\hline \multirow{2}{*}{ No. } & \multirow{2}{*}{ District } & \multicolumn{5}{c}{ Year } \\
\cline { 3 - 6 } & & 2014 & 2015 & 2016 & 2017 & 2018 \\
\hline 1. & Indramayu & $72,435.9$ & $68,737.0$ & $90,643.5$ & $77,473.6$ & $94,114.7$ \\
2. & Majalengka & $57,172.5$ & $64,394.9$ & $37,529.3$ & $60,063.8$ & $44,756.7$ \\
3. & Cirebon & $51,660.7$ & $37,443.3$ & $31,086.2$ & $39,152.2$ & $55,476.7$ \\
4. & Sumedang & $20,632.6$ & $23,491.0$ & $23,402.5$ & $28,384.5$ & $73,582.1$ \\
5. & Kuningan & $23,328.6$ & $32,108.9$ & $12,919.5$ & $29,821.8$ & $34,850.6$ \\
\hline
\end{tabular}

Source: Central Bureau of Statistics of West Java (2014-2018)

Jatibarang Sub-district is one of the sub-districts with the second-highest number of mango production in Indramayu District. Jatibarang Sub-district is also the center of the gedong gincu mango trade in Indramayu District, as well as one of the central sub-districts of mango cultivation gedong gincu. Farmers in Jatibarang Subdistrict have generally joined horticultural and food farming groups. According to Wulandari et al. (2017) it is important to motivate farmers to join farmers' groups in order to have access to financial institutions and governments through their membership in the farmers' group. Therefore, by joining the farmers' group can be an intermediary to gain access to financial institutions as well as to the government in order to get the highest minimum selling price for its business (Wulandari et al., 2020).

The harvest of mangoes in Indonesia, especially in Java, occurs in October-December. During the harvest season, because of its high production, the price of mangoes becomes very cheap that lead to the low income received by farmers. According to Putri and Esperanza (2019) the more quantity of a product will lower its selling price in the market. This was addressed by mango farmers in Jatibarang Sub-district by performing mango fertilization arrangements so that it could be harvested in the off-season by applying off season technology. According to Rasmikayati et al. (2018) mango farmers in Indramayu District who have implemented the off season reached $89 \%$, indicating that many farmers want to increase their income by applying the offseason technology.

The application off season technology is carried out by the administration of growing regulatory substances to regulate the release of mango flowers in unison in accordance with harvest planning (Food Crop Agriculture Office, 2014). In addition, 
other treatments such as the addition of organic and chemical fertilizers, pesticides and the spraying of growing regulatory substances also need to be done in the off season (Pedekawati et al., 2020). The application off season requires higher farming costs than on season, it is offset by higher selling price also so that the application off season is more profitable for farmers'.

The difference in the selling price of gedong gincu mango will affect the level of income in the off season and on season occurs due to the difference in the behavior of the farming. According to Kusumo et al. (2018) the quantity and quality of mangoes produced by farmers is strongly influenced by the behavior of mango farmers in their farming activities. Agricultural behavior is how farmers use resources efficiently and make decisions on their farms (Kusumo et al., 2019). Related to the exposure, the purpose of this study was to analyze: 1) the behavior of farmers in gedong gincu mango farming in Jatibarang Sub-district; 2) the difference of farmers' behavior in applying mango farming gedong gincu on season and off season; 3) the difference in income of gedong gincu mango farming in on season and off season.

\section{RESEARCH METHODS}

The research was conducted in Pawidean and Jatisawit villages, Jatibarang Sub-district, Indramayu District from July to September 2020. The determination of the place of research was based on the consideration of the results of interviews with the Head of The Agricultural Extension Agency, that Pawidean and Jatisawit villages have been successful and become the center of gedong gincu mango cultivation with off season technology. This research used survey methods. The data in this study was obtained directly by researchers through the filling out questionnaires of 30 respondents from Pawidean and Jatisawit villages as well as in-person interviews with informants.
According to Sugiyono (2017) a research variable is an attribute or trait or value of a person, object or activity has a certain variation set by the researcher to be studied and then drawn conclusions.

The variables in this study are as follows:

Characteristics of respondents, including age, level of education, number of household members, and farming experience.

The behavior of farmers in gedong gincu mango farming on season and off season, including maintenance by pruning, nutrition of crops by fertilizing, pest control and disease by spraying, as well as the spraying of growing regulatory substances (ZPT) to stimulate flowering in the off-season. These variables were measured through questions related to the frequency of the behavior in farming.

The income level of gedong gincu mango farming, which was calculated based on the difference in farming revenue and cost. The level of income of the farm was distinguished into the income level on season and off season.

Farmers' behavior in running farms on season and off season were analyzed with Mann Whitney tests using SPSS software. While the income of farmers according to Soekartawi (2006) is formulated as follows:

$$
\begin{aligned}
& \text { Pd }=\text { TR }- \text { TC } \\
& \text { TR }=\text { Y } \times \text { Py } \\
& \text { TC }=\text { FC }+ \text { VC }
\end{aligned}
$$

where:

$$
\begin{aligned}
& \mathrm{Pd}=\text { net income } \\
& \mathrm{TR}=\text { total revenue } \\
& \mathrm{TC}=\text { total cost } \\
& \mathrm{FC}=\text { fixed cost } \\
& \mathrm{VC}=\text { variable cost } \\
& \mathrm{Y}=\text { production } \\
& \mathrm{Py}=\text { price }
\end{aligned}
$$

\section{RESULTS AND DISCUSSION}

\section{Characteristics of Respondents}

The characteristics of respondents are personal data owned by farmers or 
research subjects who can distinguish them from other farmers.

According to the Central Bureau of Statistics (2011) the age is grouped into three categories, namely age $0-14$ years (nonproductive), $15-64$ years old (productive), and age $\geq 65$ years (nonproductive). Based on the data in Table 2 the majority of respondents in Jatibarang Sub-district are productive age groups, as many as 27 farmers (90\%) while 3 other farmers $(10 \%)$ is an unproductive age group. According to Zuriani (2017) age is very related to a person's ability to do farming especially in terms of his work productivity. The higher the age or age criteria was not productive, the lower the productivity level would be.

The age criteria of farmers in Jatibarang Sub-district are generally the criteria of productive age, where the youngest productive age is 30 years old and the oldest productive age is 60 years old. According to Batoa et al. (2008); Enete and Igbokwe (2009) in general, younger farmers have the greater physical ability and are more responsive in accepting the adoption process of innovation while older farmers have the opposite ability. Furthermore, according to Sulistyowati et al. (2015) farmers who are getting older tend to rent out their trees to other mango farmers because the physical ability in them is diminishing. Therefore, farmers in Jatibarang Sub-district are still able to manage their own farming and increase their work productivity by accepting the adoption of agricultural innovation.

Table 2. Characteristics of Respondents

\begin{tabular}{lcc}
\hline \multicolumn{1}{c}{ Variable } & $\begin{array}{c}\text { Number of } \\
\text { Respondents }\end{array}$ & Percentage (100\%) \\
\hline Age & - & - \\
Nonproductive (0-14 years old) & 27 & $90 \%$ \\
Productive (15-64 years old)) & 3 & $10 \%$ \\
Nonproductive ( $\geq$ 65 years old) & & \\
\hline Number of Household Members & 7 & $23.3 \%$ \\
0-2 Members & 18 & $60 \%$ \\
3-4 Members & 5 & $16.7 \%$ \\
5-6 Members & & \\
Level of Education & 3 & $10 \%$ \\
Having no formal education & 7 & $23.3 \%$ \\
Elementary school & 1 & $3.3 \%$ \\
Middle school & 17 & $56.7 \%$ \\
Senior school & - & - \\
Diploma & 2 & $6.7 \%$ \\
Bachelor degree & & \\
Farming Experience & 14 & $46.7 \%$ \\
1-10 Years & 10 & $33.3 \%$ \\
11-20 Years & 4 & $13.3 \%$ \\
20-30 Years & 2 & $6.7 \%$ \\
$\geq 31$ Years & & \\
\hline
\end{tabular}

Source: Processed Primary Data, 2020

The level of education was the stage of education that has been taken by a person. The level of education has an effect on the commercialization of agriculture (Martey et al., 2012). The criteria for education level in Jatibarang
Sub-district vary, ranging from not finishing school a bachelor's degree. Based on the data in Table 2 the majority of the education level of farmers in Jatibarang Sub-district is senior school as much as $56.7 \%$. This indicates the level of 
education in Jatibarang Sub-district is already high. According to Cepriadi and Yulida (2012) and Damayanti (2013) education affects the way of farmers think in managing their farming, because one's level of education and knowledge will help to think globally and thoughtfully so that it is expected to increase production. A good level of education can also encourage a person to more easily adapt to his environment (Welter and Smallbone, 2011).

The number of household members was the number of family members living together in one house and being the responsibility of the head of the family. The number of household members would determine the size of the family's needs, the more family members the more needs must be met and vice versa. Based on the data in Table 2 the majority of farmers have household members of 3-4 people which is as much as $60 \%$. According to Gustiana and Irwanto (2017) the large number of household members affects the production and consumption patterns of farmers, in addition, the large number of household members will impact the use of farm costs by farmers and impact on the distribution of agricultural income to meet the needs.

The experience of farming was a long time that had been spent by farmers to do farming. The experience of farming would affect farmers in carrying out agricultural activities that can be seen from the production. The results of research conducted by Nuthal (2009) stated that the experience of farming is an important factor in improving the ability of farmers in the management of their farms. The majority of farmers in Jatibarang Subdistrict have been farming for 1-10 years which is $46.7 \%$. The higher experience of farmers will get used to dealing with risks and solving problems in their farming difficulties (Cepriadi and Yulida, 2012). According to Lamusa (2004) the experience of doing farming determines the ability to manage a farm. Farmers who have longer farming experience will be better aware of the situation and conditions of farming faced, so that successes or failures in the past can be used as experience in carrying out better farming (Hadiana and Sumarna, 2013).

\section{The Behavior of Farmers in Applying Gedong Gincu Mango Farming On Season and Off Season}

The behavior of farmers in gedong gincu mango farming on season and off season was measured by the frequency of treatment of farmers related to maintenance by pruning, nutrition on crops by fertilizing, pest control and disease by spraying, as well as the spraying of regulatory substances growing types of paclobutrazol. This behavior was a form of treatment of gedong gincu mango farming, according to Daadi et al. (2014) the form of treatment will affect the productivity of mango farming.

Frequency is how much farmers treat their farms every season. Based on the data in Table 3 fertilizing and pruning on season and off season there is no difference in the frequency of agricultural treatment $(p>0.05)$. Farmers in Jatibarang Sub-district do it intensively with a frequency that does not differ much between farming on season and off season as a form of maintenance and nutrition in gedong gincu mango every season. According to Yuniastuti and Purbiati (2016) pruning as a form of maintenance can condition sunlight to penetrate into the plant header so that there is no attack of other disease pests.

According to the Food Crops Agriculture Office (2014) the off-season flowering time occurs in February-March, which coincides with the rainy season causing flowers to be prone to fall. Farmers need to do more maintenance in the season to maintain the production rate of mangoes so as not to lose money (Rachmat et al., 2018). So there is a difference in the frequency of spraying on season and off season $(\mathrm{p}<0.05)$. As many as $60 \%$ of farmers in Jatibarang Subdistrict do spraying with higher frequency in the off season. This is similar to 
research conducted by Pedekawati et al. (2020) that the intensity of spraying during the off season is more to overcome pest attacks and prevent flower loss. The results of other studies conducted by Ruswandi (2017) high spraying frequency in the off season as pest and disease management can decrease the damage rate by $8.81 \%$. The high intensity of spraying in the off season is also able to produce better quality fruit, according to Chomchalow and Songkhla (2008) farmers can sell good quality fruit at higher prices compared to low quality.

Off Season was not a natural time to produce gedong gincu mango, so there is a significant difference in the treatment of the spraying of growing regulatory substances $(p<0.05)$. Based on the results of Kusumo et al. (2019) most farmers in Indramayu District have implemented off season farming. Until naturally as many as $100 \%$ of farmers in Jatibarang Sub-district provide regulatory substances to grow as a stimulator for the appearance of mango flowers gedong gincu in the off-season. The factors determine farmers decision to apply technology off season one of them is the high demand for mangoes both domestically and from export markets (Kusumo et al., 2018).

The results of research conducted by Budirokhman (2016) in Cirebon district of off-season cultivation techniques by trimming the production and spraying of growing regulatory substances successfully brought mango flowers in February resulting in gedong gincu mango which is harvested starting in June with an average harvest until September $68 \mathrm{~kg}$ per tree. The difference behavior related to higher spraying frequency and applying paclobutrazol in the off season would affect the high cost of farming incurred.

\section{The Income of Gedong Gincu Mango On Season and Off Season}

According to Soekartawi (2006) agricultural income is the difference between receipts and all costs incurred for farming. In this study, the farm income per area of land owned by farmers in the off season is higher than the income of farmers on season (Table 4).

Table 3. The Behavior Farmers in Applying Gedong Gincu Mango Farming On Season and Off Season.

\begin{tabular}{|c|c|c|c|c|}
\hline \multirow{2}{*}{$\begin{array}{c}\text { Frequency of Seasonal } \\
\text { Farming Treatment }\end{array}$} & \multicolumn{2}{|c|}{ On Season } & \multicolumn{2}{|c|}{ Off Season } \\
\hline & $\mathrm{N}$ & $100 \%$ & $\mathrm{~N}$ & $100 \%$ \\
\hline \multicolumn{5}{|l|}{ Fertilizing } \\
\hline $0-1$ & 2 & $6.7 \%$ & - & - \\
\hline $2-3$ & 27 & $90 \%$ & 24 & $80 \%$ \\
\hline $4-5$ & 1 & $3.3 \%$ & 6 & $20 \%$ \\
\hline \multicolumn{5}{|c|}{$p=0.131$} \\
\hline \multicolumn{5}{|l|}{ Pruning } \\
\hline $0-1$ & 1 & $3.3 \%$ & - & - \\
\hline $2-3$ & 25 & $83.3 \%$ & 24 & $80 \%$ \\
\hline $4-5$ & 4 & $13.3 \%$ & 6 & $20 \%$ \\
\hline \multicolumn{5}{|c|}{$p=0.395$} \\
\hline Spraying & & & & \\
\hline $0-10$ & 5 & $16.7 \%$ & 1 & $3,3 \%$ \\
\hline $11-20$ & 20 & $66.7 \%$ & 11 & $36,7 \%$ \\
\hline $21-30$ & 5 & $16.7 \%$ & 18 & $60 \%$ \\
\hline \multicolumn{5}{|c|}{$p=0.03$} \\
\hline Applying Paclobutrazol & & & & \\
\hline Yes & - & - & 30 & $100 \%$ \\
\hline No & 30 & $100 \%$ & - & - \\
\hline
\end{tabular}


Table 4. Average Income of Gedong Gincu Mango On Season and Off Season

\begin{tabular}{lcc}
\hline \multicolumn{1}{c}{ Components (Average) } & On Season & Off Season \\
\hline Total Production $(\mathrm{Kg})$ & $6,802 \mathrm{Kg}$ & $4,472 \mathrm{Kg}$ \\
Selling Price (Rp/Kg) & IDR 9,700 & IDR 25,200 \\
Total Cost (Rp) & IDR $49,158,906$ & IDR $58,301,573$ \\
Total Revenue (Rp) & IDR $64,787,067$ & IDR $109,727,833$ \\
Net Income (Rp) & IDR $16,114,027$ & IDR $52,680,594$ \\
\hline
\end{tabular}

Source: Processed Primary Data, 2020

According to Akcay and Uzunoz (2005) it is important for farmers to detail the total cost of farming so that they can know the amount of income received. Components to know the income of farmers on season and off season are the total production, selling price, total cost, and total revenue. The total cost of farming off season will be higher due to the high frequency of spraying and spraying of paclobutrazol, although the higher cost of farmers but the farmers have higher benefit (Awaliyah, 2018).

Based on the results of an interview with the Chairman of the Agricultural Extension Board of Jatibarang Sub-district, the price of gedong gincu mango from farmers in the harvest season only reached IDR $6,000-12,000$ per $\mathrm{kg}$, while in the off season the selling price reached IDR 24,000 - 30,000 per kg. Table 4 shows the average off season production is lower than on season, which it reaches $4,472 \mathrm{~kg}$. Low off-season production is offset by the high selling price which reaches an average of IDR 25,200 per $\mathrm{kg}$, farming is more profitable with average income per season reaching IDR 52,680,594 per 1.4 hectares of average farmer's land area. Other research related to off season farming conducted by Hakim et al. (2017) on shallot commodities is also profitable with an average profit difference of IDR $1,402,870$ which is influenced by the greater selling price and acceptance in the off season of shallots. It is also in line with research conducted by Saefudin et al. (2019) using off season technology to get a higher mango selling price and allow farmers to have two harvest seasons in one year. Furthermore Pedekawati et al. (2020) stated that off season farming is more profitable so that it can be the choice of farmers to increase their agricultural income.

\section{CONCLUSION AND SUGGESTION}

Off season was not a natural time to produce gedong gincu mango, so there are differences in farmer behavior related to the frequency of spraying and applying paclobutrazol as a growing regulatory substance while the behavior of farmers related to the frequency of fertilization and pruning there was no difference.

The differences farmers' behavior related to the frequency of spraying and applying paclobutrazol in the off season have an effect on higher farming costs. However, the selling price of gedong gincu mango in the off season was higher reached IDR 25,200 per $\mathrm{kg}$, so the income received by farmers was much higher and more profitable with the difference in average income reaching IDR 36,566,567.

Based on the above conclusions, gedong gincu mango farming off season conducted by farmers proved more profitable. However, the treatment of farmers with high frequency of spraying and applying paklobutrazol was feared to interfere with the growth and health of gedong gincu mango plants. Therefore, there needs to be further research related to the topic of agronomic review of the application off season technology in gedong gincu mango farming.

\section{REFERENCES}

Akcay, Y., dan Uzunoz, M. An Investment Analysis of Peach and Cherry 
Growing in Turkey. Journal of Applied Sciences, 2005 5(9), 16651668.

Awaliyah, F. Keragaan Agribisnis Komoditas Mangga Gedong Gincu di Kabupaten Cirebon. MAHATANI, 2018 1(2), 129-141.

Badan Pusat Statistik. (2011). Angka Beban Tanggungan. Jakarta: Badan Pusat Statistik.

Badan Pusat Statistik. (2018). Produksi Buah-buahan Menurut Provinsi. Jakarta: Badan Pusat Statistik.

Bakhsh, K., Hassan, I., dan Akhter, M. Profitability and Cost in Growing Mango Orchards. Journal Agriculture Social Sciences, 2006 2(1), 46-50.

Batoa, H., Jahi, A., dan Susanto, D. Faktor-faktor yang Berhubungan dengan Kompetensi Petani Rumput Laut di Kabupaten Konawe Provinsi Sulawesi Tenggara. Jurnal Penyuluhan, 2008 4(1), 30-38.

Budirokhman, D. Peningkatan Produktivitas dan Kualitas Buah Mangga (Mangifera Indicia L) CV. Gedong Gincu Melalui Penerapan Teknologi Off Season dan Penyiraman Melalui Teknologi Drip Irrigation Sebagai Upaya Meningkatan Ekspor Buah Nasional. Seminar Nasional Dan Gelar Produk. 2016, 187-194.

Cepriadi dan Yulida, Roza. Presepsi Petani Terhadap Usahatani Lahan Pekarangan (Studi Kasus Usahatani Lahan Pekarangan di Kecamatan Kerinci Kabupaten Pelalawan). Indonesian Journal of Agricultural Economics, 2012 3(2), 177-194.

Chomchalow N dan Songkhla P. Thai Mangor Export: a Slow-ButSustainable Development. $A U$
Journal of Technology, 2008 12(1), $1-8$.

Daadi, B.E., Gazali, I., and Amikuzuno, J. Technical Efficiency Analysis of Organic Mango Out-grower Farm Management Types: The Case of Integrated Tamale Fruit Company (ITFC) Out-growers in Northern Region. Africal Journal of Agriculture Economics and Rural Development, 2014 2(3), 129-137.

Damayanti, L. Faktor-faktor yang Memengaruhi Produksi, Pendapatan dan Kesempatan Kerja pada Usahatani Padi Sawah di Daerah Irigasi Parigi Moutong. SEPA, 2013 9(2), 249-259.

Dinas Pertanian Tanaman Pangan. SOP Mangga Gedong Gincu Off Season. Bandung: Dinas Pertanian Tanaman Pangan Jawa Barat. 2014

Dittmar, H., dan Drury, J. Self Imaget- Is it bag? A Qualitative Comparison Between Ordinary and Excessive Consumers. Journal of Economics Pshychology, 2000 21(2), 109-142.

Enete, A.A., dan Igbokwe, E. M. Cassava Market Participation Decision of Household in Africa. Tropicultura, 2009 27(3), 129-136.

Gustiana, C., dan Irwanto. Pengaruh Biaya Produksi, Pengalaman, dan Keterampilan Terhadap Pendapatan Usahatani Kakao (Theobroma cacao) Di Kecamatan Karang Baru Kabupaten Aceh Tamiang. AGRISAMUDRA, Jurnal Penelitian, 2017 4(2), 67-76.

Hadayanti, Didit., Deliana. Y., N. R. Faktor Dominan dari Preferensi Konsumen dalam Pemilihan Jenis Mangga : Studi Kasus di Supermarket Kota Bandung. Jurnal Agrikultura, 2016 27(2), 94-101. 
Hadiana, D., dan Sumarna, A. Usahatani Mangga Gedong Gincu Berdasarkan Status Penguasaan Lahan: Studi Kasus di Desa Sidamukti Kecamatan Majalengka Kabupaten Majalengka. Jurnal Ilmu Pertanian Dan Peternakan, 2013 1(2), 56-77.

Hakim, A.R., Rajiman, dan Nalinda, R. Analisis Nilai Ekonomi Usahatani Bawang Merah Off Season dan In Season Pada Lahan Pasir Pantai (Studi Kasus di Desa Srigading Kecamatan Sanden Kabupaten Bantul DIY). SEPA, 2017 14(1), 53-60.

Kusumo, R.A.B., Rasmikayati, E., Karyani, T., Mukti, G. Perbandingan Perilaku Usahatani Pada Dua Sentra Produksi Mangga di Provinsi Jawa Barat (Kasus di Kabupaten Indramayu dan Kuningan). Jurnal Pemikiran Masyarakat Ilmiah Berwawasan Agribisnis, 2019 5(2), 134-144.

Kusumo, R.A.B., Rasmikayati, E., Mukti, G. Perilaku Petani dalam Usahatani Mangga di Kabupaten Cirebon. Jurnal Pemikiran Masyarakat Ilmiah Berwawasan Agribisnis, 2018 4(2), 197-209.

Kusumo, R.A.B., Rasmikayati, E., Mukti G.W., Fatimah, S., Saefudin, B. Faktor-faktor yang Mempengaruhi Keputusan Petani Mangga dalam Menerapkan Teknologi Off Season di Kabupaten Cirebon. Jurnal Pemikiran Masyarakat Ilmiah Berwawasan Agribisnis, 2018 4(1), 57-69.

Lamusa, A. Faktor-faktor yang Memengaruhi Produksi Tomat: Suatu Kasus di Wilayah Kebun Kopi Kecamatan Tawaili Kabupaten Donggala. Journal Agrisains, 2004 5(1), 35-42.

Martey, E., Al-Hassan, R., dan Kuwornu, J. K. Commercialization of
Smallholder Agriculture in Ghana, A Tobit Regression Analysis. African Journal of Agricultural Research, 2012 7(14), 2131-2141.

Nuthall, P. (2009). Modelling The Origins of Managerial Ability in Agricultural Production. The Australian Journal of Agricultural and Resource Economic. 2009. 53, 413-436.

Pedekawati, Cindi., Karyani. T., Sulistyowati, L. (2020). Uji Beda Pendapatan Usahatani Mangga Gedong Gincu Pada Saat On Season dan Off Season. Jurnal Ilmu Pertanian, 2020 2(2), 82-89.

Putri, G.R., dan Esperanza, D. Kajian Perilaku Adaptasi Petani Mangga Terhadap Perubahan Iklim di Kecamatan Panyingkiran Kabupaten Majalengka. Jurnal Ilmiah Mahasiswa AGROINFO GALUH, 2019 6(1), 122-131.

Rasmikayati, Elly., Wibawa. G., Andriani. R., dan Saefudin, B. Kajian Potensi dan Kendala dalam Proses Usahatani dan Pemasaran Mangga di Kabupaten Indramayu. Jurnal Ilmu-Ilmu Sosial Dan Humaniora, 2018 20(3), 215221.

Rizkia, Herfiani. Pengembangan Sistem Persediaan Dalam Rantai Pasok Mangga Gedong Gincu. Institut Pertanian Bogor. 2012.

Ruswandi, A. Nilai Ekonomi Pengendalian Lalat Buah pada Mangga Gedong Gincu: Studi Kasus di Desa Jembar Wangi Kecamatan Tomo, Sumedang. Creative Research Journal, 2017 3(1), 25-36.

Saefudin, B.R., Rasmikayati, E., Dwirayani, D., Awaliyah, F., dan Rachmah, A.D. (2019). Fenomena Peralihan Usahatani Mangga ke Padi di Kecamatan Sedong, Kabupaten Cirebon, Jawa Barat. Jurnal Paradigma Agribisnis, 2019 2(2), 21-33. 
Soekartawi. (2006). Analisis Usahatani. UI Press.

Statistik Tanaman Buah-buahan dan Sayuran Tahunan. Statistik Tanaman Buah-buahan dan Sayuran Tahunan. Jakarta: Badan Pusat Statistik. 2018

Sugiyono. Metode Penelitian Kuantitatif. Bandung: Alfabeta. 2017

Sulistyowati, L., Natawidjaja, R.S., dan Rahman, N. Adoption of Technology and Economics Efficiency of The Smallholder Mango Farmers in Indonesia. International Journal of Applied Business and Economic Research, 2015 13(7), 4621-4645.

Welter, F., dan Smallbpne, D. Institutional Perspective on Enrepreneurial Behaviour in Challenging Environments. Journal of Small Business Management, 2011 49(1).

Wulandari, E., Meuwissen, M., Karmana, M., dan Oude Lansink, A. (2017).
Access to Finance from Different Finance Provider Types: Farmer Knowledge of the Requirements. PloS ONE, 12(9), 1-5.

Wulandari, E., Supyandi, D., dan Ernah. The Risk Measurement of Horticultural Price: A Comparison Based on Financial Access in West Java, Indonesia. Sains Malaysiana, 2020 49(3), 713-719.

Yuniastuti, S., dan Purbiati, T. Pengaruh Penambahan Pupuk Hayati dan PPC Terhadap Keberhasilan Pembuahan Mangga Podang di Luar Musim (Effect of Biofertilizer and Liquid Fertilizer on Off Season Podang Mango Fruiting Success). Jurnal Hortikultura, 2016 26(2), 2017-2216.

Zuriani. Keterkaitan Dan Dampak Karakteristik Sosial Petani Terhadap Produksi Padi di Kabupaten Aceh Utara. Jurnal Agrifo, 2017 2(1), $30-40$. 